Article

\title{
Anti-Inflammatory Effects of $5 \alpha, 8 \alpha$-Epidioxycholest-6-en-3 $\beta$-ol, a Steroidal Endoperoxide Isolated from Aplysia depilans, Based on Bioguided Fractionation and NMR Analysis
}

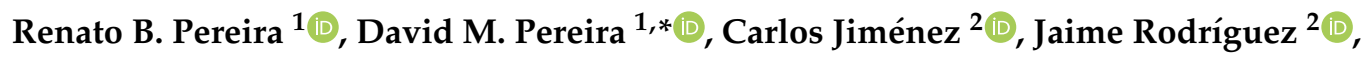 \\ Rosa M. Nieto ${ }^{2}$, Romeu A. Videira ${ }^{1}$, Olga Silva ${ }^{3}$, Paula B. Andrade ${ }^{1}\left(\mathbb{D}\right.$ and Patrícia Valentão ${ }^{1, *}$ \\ 1 REQUIMTE/LAQV, Laboratório de Farmacognosia, Departamento de Química, Faculdade de Farmácia, \\ Universidade do Porto, R. Jorge Viterbo Ferreira, n 228, 4050-313 Porto, Portugal; \\ ren.pereira@gmail.com (R.B.P.); ravideira@gmail.com (R.A.V.); pandrade@ff.up.pt (P.B.A.) \\ 2 Departamento de Química, Facultade de Ciencias e Centro de Investigacións Científicas Avanzadas (CICA), \\ Universidade da Coruña, E-15071 A Coruña, Spain; carlos.jimenez@udc.es (C.J.); \\ jaime.rodriguez@udc.es (J.R.); rosa.nieto@udc.es (R.M.N.) \\ 3 Research Institute for Medicines (iMed.ULisboa), Faculty of Pharmacy, Universidade de Lisboa, Av. \\ Professor Gama Pinto, 1649-003 Lisbon, Portugal; osilva@campus.ul.pt \\ * Correspondence: dpereira@ff.up.pt (D.M.P.); valentao@ff.up.pt (P.V.); \\ Tel.: +35-122-042-8653 (P.V.); Fax: +35-122-609-3390 (P.V.)
}

Received: 16 April 2019; Accepted: 29 May 2019; Published: 3 June 2019

\begin{abstract}
Sea hares of Aplysia genus are recognized as a source of a diverse range of metabolites. $5 \alpha, 8 \alpha$-Endoperoxides belong to a group of oxidized sterols commonly found in marine organisms and display several bioactivities, including antimicrobial, anti-tumor, and immunomodulatory properties. Herein we report the isolation of $5 \alpha, 8 \alpha$-epidioxycholest-6-en-3 $\beta$-ol $(\mathrm{EnP}(5,8))$ from Aplysia depilans Gmelin, based on bioguided fractionation and nuclear magnetic resonance (NMR) analysis, as well as the first disclosure of its anti-inflammatory properties. $\operatorname{EnP}(5,8)$ revealed capacity to decrease cellular nitric oxide (NO) levels in RAW 264.7 macrophages treated with lipopolysaccharide (LPS) by downregulation of the Nos2 (inducible nitric oxide synthase, iNOS) gene. Moreover, $\operatorname{EnP}(5,8)$ also inhibited the LPS-induced expression of cyclooxygenase-2 (COX-2), interleukin 6 (IL-6), and tumor necrosis factor alpha (TNF- $\alpha$ ) at the mRNA and protein levels. Mild selective inhibition of COX-2 enzyme activity was also evidenced. Our findings provide evidence of $\operatorname{EnP}(5,8)$ as a potential lead drug molecule for the development of new anti-inflammatory agents.
\end{abstract}

Keywords: Aplysia depilans; $5 \alpha, 8 \alpha$-epidioxycholest-6-en-3 $\beta$-ol; iNOS; COX-1; COX-2; IL-6; TNF- $\alpha$

\section{Introduction}

Aplysia sea hares are herbivorous mollusks that feed on a wide variety of green, red, and brown algae $[1,2]$. Indeed, it is worth mentioning the ability of these sea hares to use algae as a source of metabolites of their chemical defense system [1,3]. Moreover, Aplysia spp. complex digestive gland contributes to its metabolic machinery, leading to the production of innumerable compounds with interesting pharmacological properties [1,3,4]. Although the majority of secondary Aplysia metabolites have been extensively explored due to their cytotoxic and antibacterial properties, few reports address their anti-inflammatory activity.

During the last decades, marine organisms were shown to be a source of unconventional sterols. In particular, steroidal endoperoxides are a subgroup of steroids which are ubiquitously found in 
marine invertebrates, such as sponges, and sea hares, among others [5]. These marine sterols have been reported to possess diverse biological properties like anti-tumor, immunomodulatory, antiviral, and antifouling activities, being considered as lead drug compounds in the development of new pharmacological agents [6]. The $5 \alpha, 8 \alpha$-endoperoxides belong to a group of oxidized sterols derivatives resulting from the addition of an oxygen to a 5,7-diene system in the molecule of the precursor sterol [6]. Ergosterol peroxide is the best-known representative of this class, displaying anti-inflammatory properties that are associated to its capacity to inhibit the production of pro-inflammatory mediators and the activation of nuclear factor kappa B (NF-кB) signaling pathway [7]. The cholesterol derivative $5 \alpha, 8 \alpha$-epidioxycholest-6-en-3 $\beta$-ol $(\mathrm{EnP}(5,8))$ is another oxidized sterol that has been found in different species of sea hares [8,9], sea urchins, and cone snails [10-12]. Among the few studies addressing its biological activity, Minh et al. reported a strong cytotoxic effect against various cancer cell lines, namely human epidermoid carcinoma (KB), fibrillary sarcoma of uterus (FL), and human hepatocellular carcinoma (HepG-2) with $\mathrm{IC}_{50}$ values of $4.8,9.4$, and $5.8 \mu \mathrm{M}$, respectively [13]. More recently, Clark et al. found antileishmanial properties towards the amastigote form of Leishmania donovani, displaying an $\mathrm{IC}_{50}$ of $4.9 \mu \mathrm{M}[14]$.

Herein, we report the isolation of $\operatorname{EnP}(5,8)$, based on bioguided fractionation and nuclear magnetic resonance (NMR) analysis, from a non-polar fraction of Aplysia depilans Gmelin methanolic extract, and the first disclosure of the molecular mechanisms underlying its anti-inflammatory properties in RAW 264.7 macrophages. Additionally, its capacity to inhibit 5-lipoxygenase (5-LOX), phospholipase $\mathrm{A}_{2}\left(\mathrm{PLA}_{2}\right)$, and cyclooxygenases (COX-1 and COX-2) was also explored.

\section{Results and Discussion}

\subsection{Effect of Non-Polar Fraction of A. depilans Extract}

\subsubsection{RAW 264.7 Macrophage Viability}

Continuing our ongoing research on the anti-inflammatory activity of Aplysia metabolites [1,4,15-17], this work gives particular attention to the lipophilic molecules. Prior to the assessment of the anti-inflammatory activity of the non-polar fraction of the A. depilans extract (see Section 3.3.), RAW 264.7 macrophages were incubated with five different concentrations of the extract $(25-400 \mu \mathrm{g} / \mathrm{mL})$ to find the non-cytotoxic concentrations. Macrophages viability was evaluated based on the reduction of 3-(4,5-dimethylthiazol-2-yl)-2,5-diphenyltetrazolium bromide (MTT) and lactate dehydrogenase (LDH) leakage assay, which are indicative of the mitochondrial activity and membrane integrity of the cells, respectively. As can be seen in Figure 1, the non-polar fraction of $A$. depilans extract was not cytotoxic at concentrations lower or equal to $100 \mu \mathrm{g} / \mathrm{mL}$, which were used to perform subsequent experiments.
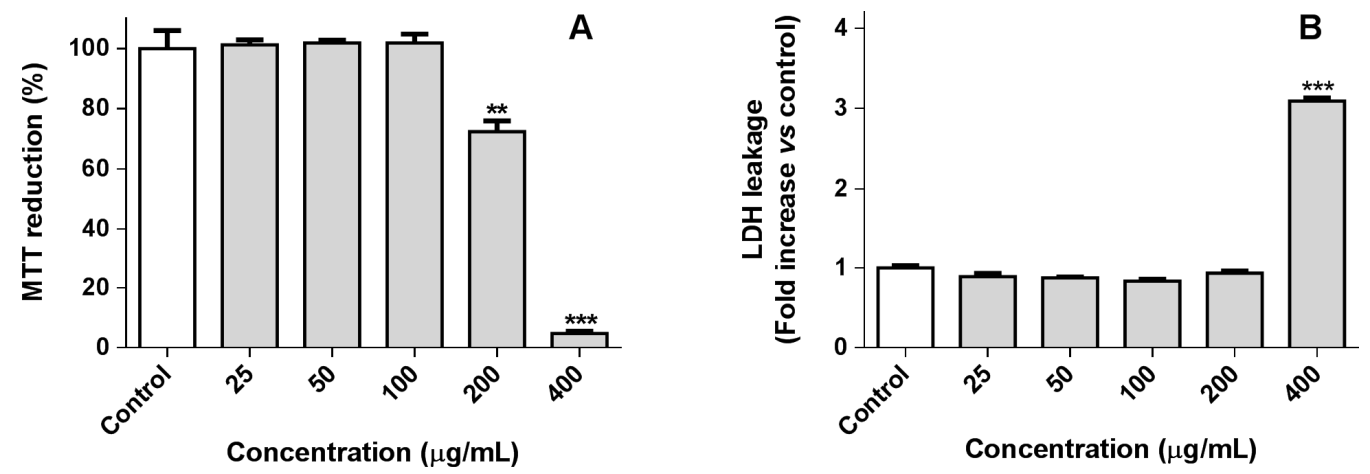

Figure 1. Effect of non-polar fraction of Aplysia depilans extract on 3-(4,5-dimethylthiazol-2-yl)2,5-diphenyltetrazolium bromide (MTT) reduction (A) and lactate dehydrogenase (LDH) leakage (B) of RAW 264.7 macrophages. Results are expressed as mean \pm standard error of the mean (SEM) of at least three independent experiments. ${ }^{* *} p<0.01,{ }^{* * *} p<0.001$. 


\subsubsection{Cellular Nitric Oxide Levels}

Nitric oxide (NO) is an important signaling molecule synthesized by many cells in response to homeostatic and pathologic stimuli [18]. Although it was first described as a vasodilator, having a preponderant role in blood pressure, its association with the pathogenesis of several inflammatory conditions is fully established nowadays [18]. In the cell model used, a pro-inflammatory phenotype was induced using lipopolysaccharide (LPS), an endotoxin that triggers several inflammatory mediators, including NO. As can be seen in Figure 2, the pre-incubation of the non-polar fraction of A. depilans extract for $2 \mathrm{~h}$ leads to a decrease in cellular NO levels with an $\mathrm{IC}_{50}$ of $66.42 \mu \mathrm{g} / \mathrm{mL}$. In order to find the compound(s) responsible for this effect, a bioguided fractionation of the above-mentioned fraction was performed, based on its capacity to reduce the cellular NO levels.
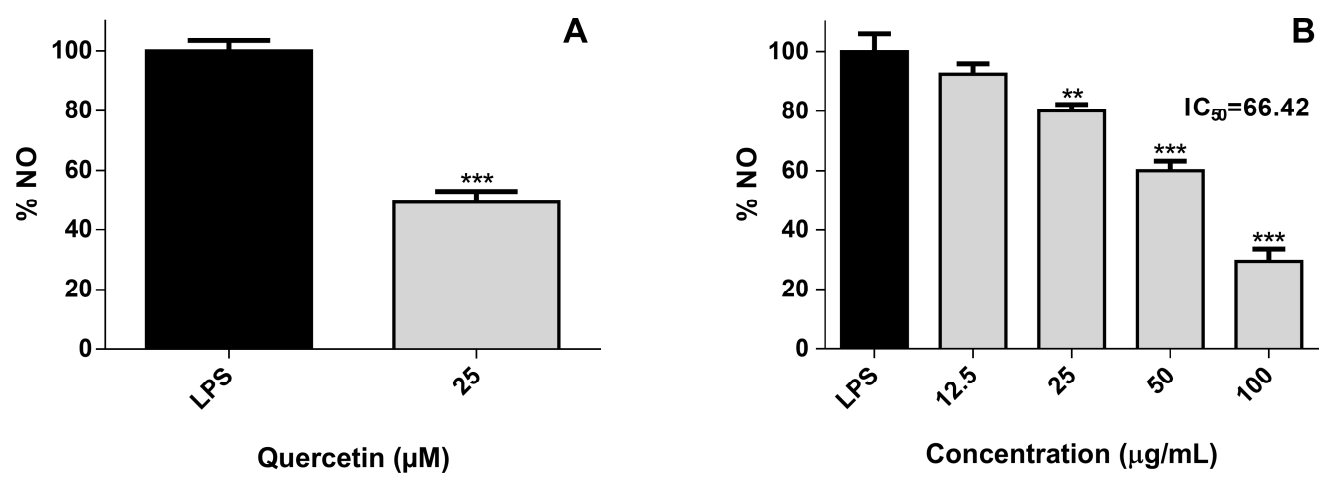

Figure 2. Effect in nitric oxide (NO) levels of cells pre-treated for $2 \mathrm{~h}$ with quercetin at $25 \mu \mathrm{M}(\mathrm{A})$ and with the non-polar fraction of $A$. depilans extract (B), followed by $22 \mathrm{~h}$ co-treatment with $1 \mu \mathrm{g} / \mathrm{mL}$ of lipopolysaccharide (LPS). Results are expressed as mean \pm SEM of at least three independent experiments. ${ }^{* *} p<0.01,{ }^{* * *} p<0.001$.

\subsection{Effect of A. depilans Non-Polar Extract Sub-Fractions}

Due to its promising anti-inflammatory activity, the non-polar fraction of $A$. depilans extract was fractionated, affording 11 fractions (Fr1-Fr11), according to the procedure described in Material and Methods (Section 3.4.). Then, as reported above for the crude extract, the effect of Fr1-Fr11 on MTT reduction was evaluated in RAW 264.7 macrophages (Figure S1A). Afterwards, the non-cytotoxic concentrations were screened for their ability to reduce the cellular NO levels, in order to find the most active fraction (Figure S1A). Despite the interesting activity demonstrated by Fr8, the $\mathrm{IC}_{50}$ could not be determined once this fraction was cytotoxic at concentrations higher or equal to $25 \mu \mathrm{g} / \mathrm{mL}$. Fr6 was the fraction displaying the lowest determined $\mathrm{IC}_{50}$ value $(25.60 \mu \mathrm{g} / \mathrm{mL})$, significant differences being found for all tested concentrations $(p<0.05)$ (Figure S1A), which indicates the presence of active molecule(s). Hereupon, Fr6 was re-fractionated, leading to the isolation of the natural steroidal endoperoxide EnP(5,8) (Figure S1B, NMR data-Section $3.4[12,13]$ ). In order to evaluate the relevance of this compound to the anti-inflammatory properties of Fr6, the levels of NO after a pre-incubation with different concentrations of $\operatorname{EnP}(5,8)$ were measured.

\subsection{Anti-Inflammatory Effect of EnP(5,8)}

\subsubsection{RAW 264.7 Macrophages Viability}

As can be seen in Figure 3A, the $\operatorname{EnP}(5,8)$ at $1.3-20.8 \mu \mathrm{g} / \mathrm{mL}(3.125-50 \mu \mathrm{M})$ had no significant effect on the cell viability $(p>0.05)$. Of note, in a promonocytic human cell line (THP-1), the structurally related ergosterol peroxide has demonstrated the capacity to dose-dependently $(1-20 \mu \mathrm{M})$ increase the protection of cells against LPS-induced toxicity [7]. Relevantly, $\operatorname{EnP}(5,8)$ displayed an interesting anti-inflammatory effect: at $10.4 \mu \mathrm{g} / \mathrm{mL}(25 \mu \mathrm{M})$ the NO levels were reduced c.a. $40 \%$ in comparison with LPS $(p<0.001)$ (Figure 3B). Thus, our findings confirm the preliminary results reported by Huang 
et al. [19] on the ability of $\operatorname{EnP}(5,8)$ to reduce cellular NO levels. Of note, the same study carried out with some $\operatorname{EnP}(5,8)$ analogues evidenced that while the unsaturation at $\mathrm{C} 22$ does not appear to be a structural requirement for $\mathrm{NO}$ reduction, the substitution of $\mathrm{C} 24$ by an ethyl group apparently decreases its activity [19]. Multiple mechanisms of action can be involved in the observed effect: firstly, the $\operatorname{EnP}(5,8)$ can exert antioxidant activity, leading to a decrease of ${ }^{\circ} \mathrm{NO}$ level; secondly, $\operatorname{EnP}(5,8)$ can inhibit inducible nitric oxide synthase (iNOS), triggering a reduction in NO and L-citrulline levels; and thirdly, the $\operatorname{EnP}(5,8)$ can modulate several pathways, leading to a decrease on iNOS mRNA and protein expression. In order to clarify the mechanism underlying its activity, $\operatorname{EnP}(5,8)$ was assessed for its capacity to scavenge ${ }^{\bullet} \mathrm{NO}$ and to modulate iNOS action.
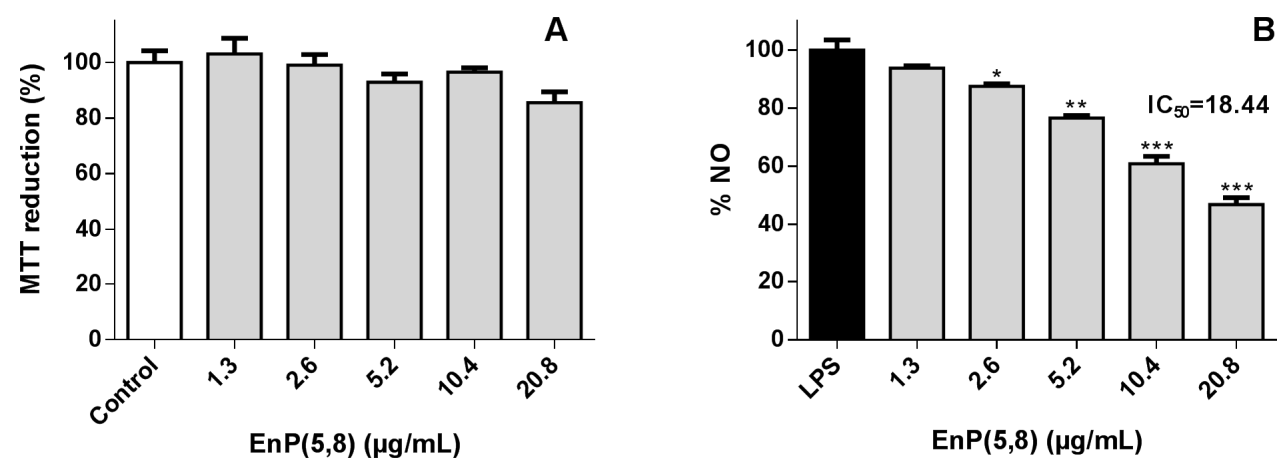

Figure 3. (A) Effect of $5 \alpha, 8 \alpha$-epidioxycholest-6-en-3 $\beta$-ol $(\operatorname{EnP}(5,8))$ on MTT reduction of RAW 264.7 macrophages. (B) Effect in NO levels of cells pre-treated for $2 \mathrm{~h}$ with $\mathrm{EnP}(5,8)$, followed by 22-h co-treatment with $1 \mu \mathrm{g} / \mathrm{mL}$ of LPS. Results are expressed as mean \pm SEM of at least three independent experiments. ${ }^{*} p<0.05,{ }^{* *} p<0.01,{ }^{* * *} p<0.001$.

\subsubsection{Nitric Oxide Radical ( $\left.\bullet^{\mathrm{NO}}\right)$ Scavenging Assay}

Multiple antioxidant molecules have been associated to a decrease on NO production in LPS-stimulated macrophages, by a direct scavenging effect of ${ }^{\bullet} \mathrm{NO}$ [20]. Herewith and using a cell-free assay, the ${ }^{\circ} \mathrm{NO}$ scavenging activity of $\operatorname{EnP}(5,8)$ was investigated, at the same concentrations tested for cellular NO (up to $20.8 \mu \mathrm{g} / \mathrm{mL}$ ), which revealed no antioxidant effect (data not shown).

\subsection{3. iNOS Direct Inhibition}

According to our method [15] and based on the conversion of L-arginine to equimolar amounts of NO and L-citrulline, the levels of these products can be used as markers of iNOS activity. Cells without LPS activation showed negligible activity, as expected (data not shown). As can be seen in Figure 4, the pre-incubation of the LPS-activated RAW 264.7 cells with the commercial inhibitor $N$-methyl-L-arginine significantly inhibited iNOS enzyme activity at $25 \mu \mathrm{M}$, decreasing to the same extent NO and L-citrulline levels $(p<0.01)$. On the other hand, no significant differences were found with the pre-incubation with $\operatorname{EnP}(5,8)(p>0.05)$ (Figure 4), indicating that this molecule cannot directly inhibit iNOS enzyme activity. Once the reduction of the cellular NO levels reported in Figure 3B cannot be explained by a scavenging effect and/or to an enzyme inhibition process, the interference of $\mathrm{EnP}(5,8)$ with respect to the iNOS gene and protein expression was further studied. 


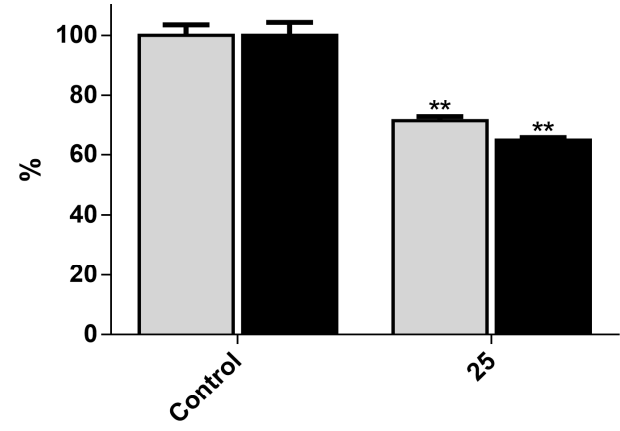

$\mathrm{N}$-methyl-L-arginine $(\mu \mathrm{M})$

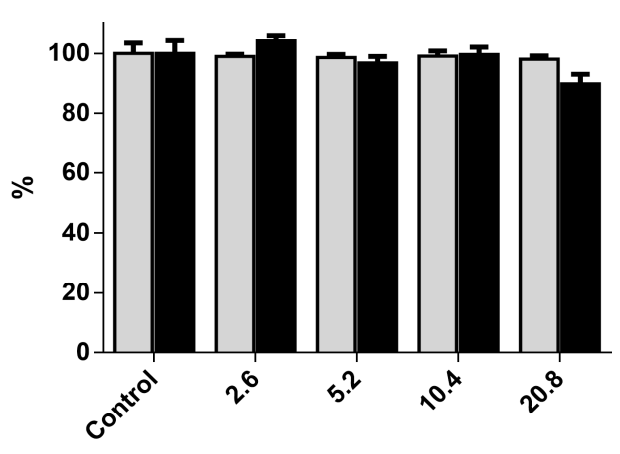

$\operatorname{EnP}(5,8)(\mu \mathrm{g} / \mathrm{mL})$

\section{NO L-citrulline}

Figure 4. Effect of $\operatorname{EnP}(5,8)$ on the cellular levels of $\mathrm{NO}$ and L-citrulline, the two bio-products of inducible nitric oxide synthase (iNOS) activity. $N$-methyl-L-arginine was used as a positive control. The results correspond to the mean \pm SEM of at least three independent experiments performed in duplicate. ${ }^{* *} p<0.01$.

2.3.4. iNOS, COX-2, Interleukin 6 (IL-6), and Tumor Necrosis Factor Alpha (TNF- $\alpha$ ) mRNA and Protein Expression

NF- $\mathrm{KB}$ has been shown to play an important role in regulating the expression of pro-inflammatory genes, including cytokines, chemokines, and adhesion molecules, which are involved in cell survival, immunity and inflammatory processes [21]. In RAW 264.7 macrophages, LPS is used to stimulate an inflammatory response, through NF- $\mathrm{KB}$ activation, leading to a marked increase in iNOS, COX-2, interleukin-6 (IL-6), and tumor necrosis factor alpha (TNF- $\alpha$ ) expression [21]. As can be seen in Figure S2, the model is appropriate to study these events, as cells challenged with LPS expressed higher amounts of iNOS, COX-2, IL-6, and TNF- $\alpha$ mRNA, evidenced by the significant decrease observed in the number of amplification cycles (Ct values) $(p<0.001)$.

Since $\operatorname{EnP}(5,8)$ was found to decrease NO production, without any capacity to scavenge ${ }^{\bullet} \mathrm{NO}$ and/or to inhibit iNOS activity, we performed qPCR and western blotting to determine if the observed effects were related to iNOS expression. In addition and once LPS treatment also increased the mRNA and protein levels of COX-2, IL-6, and TNF- $\alpha$, the effect of $\operatorname{EnP}(5,8)$ on them was also explored.

The qPCR analysis showed that the expressions of iNOS, COX-2, IL- 6 and TNF- $\alpha$ mRNA were significantly inhibited $(43 \%, 28 \%, 38 \%$ and $15 \%$, respectively) by $\operatorname{EnP}(5,8)$ at $10.4 \mu \mathrm{g} / \mathrm{mL}(25 \mu \mathrm{M})$ $(p<0.05)$ (Figure 5A). A similar effect was also reported with ergosterol peroxide, which demonstrated the ability to down-regulate mRNA expression of iNOS and COX-2 at $30 \mu \mathrm{M}$ [22]. Moreover, western blotting analysis evidenced that iNOS protein levels were associated with their mRNA expression (Figure 5), suggesting that the observed reductions in $\mathrm{NO}$ production by $\operatorname{EnP}(5,8)$ were due to a transcriptional suppression of iNOS. Similarly, an apparent inhibition on iNOS protein expression was also noted by $\mathrm{Lu}$ et al. [23] upon treatment with an $\operatorname{EnP}(5,8)$ analogue, containing an extra methyl group on $\mathrm{C} 24$ of the side chain. Interestingly, a markedly increased activity was observed when the C24 methyl substitution was accompanied by cyclisation, arising a cyclopropane in the saturated side chain [23]. Concerning COX-2 protein expression, no significant inhibition was described for both $\operatorname{EnP}(5,8)$ analogues [23], which is in agreement with our findings (Figure 5B). Of note, the protein levels of COX-2, IL-6, and TNF- $\alpha$ were also associated with their mRNA expression (Figure 5). Curiously, a previous study involving different sterols and conducted in HEK293 cells transfected with an NF- $\kappa B$-promoted luciferase reporter demonstrated the inhibitory capacity of $5 \alpha, 8 \alpha$-epidioxysterols on 12-O-tetradecanoylphorbol-13-acetate (TPA)-induced NF-kB luciferase activity [24]. The EnP $(5,8)$ and its C22 unsaturated analogue proved this capacity, the latter being c.a. 3.2 fold more active [24]. Based on those findings, the authors suggested the $5 \alpha, 8 \alpha$-epidioxy as the active group and that the branched chain affects the potency of these molecules [24]. Herewith, the effects of $\operatorname{EnP}(5,8)$ observed 
on iNOS, COX-2, IL-6, and TNF- $\alpha$ mRNA and protein expression may be related to a down-regulation of this signaling pathway.

A
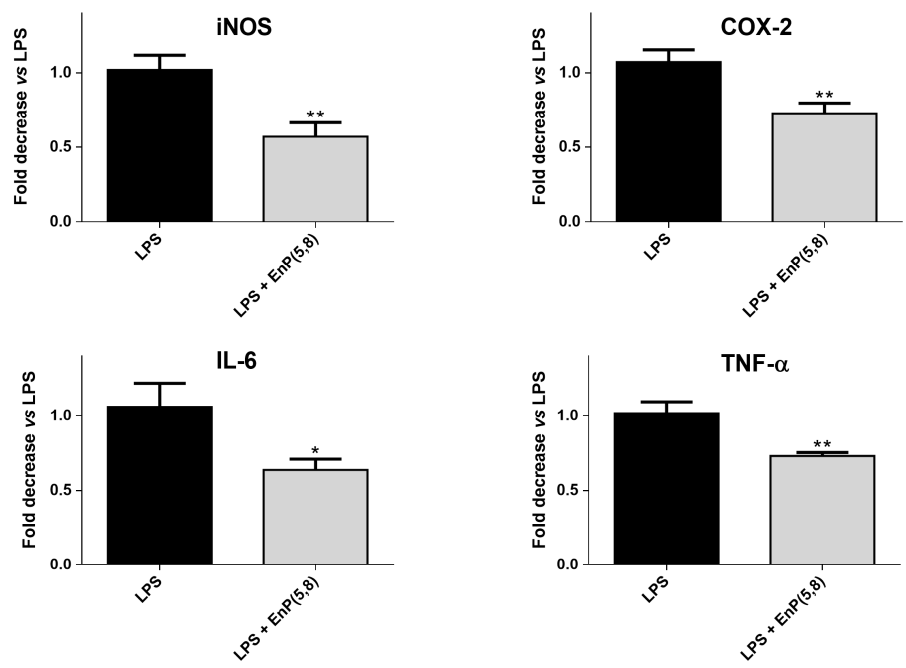

B
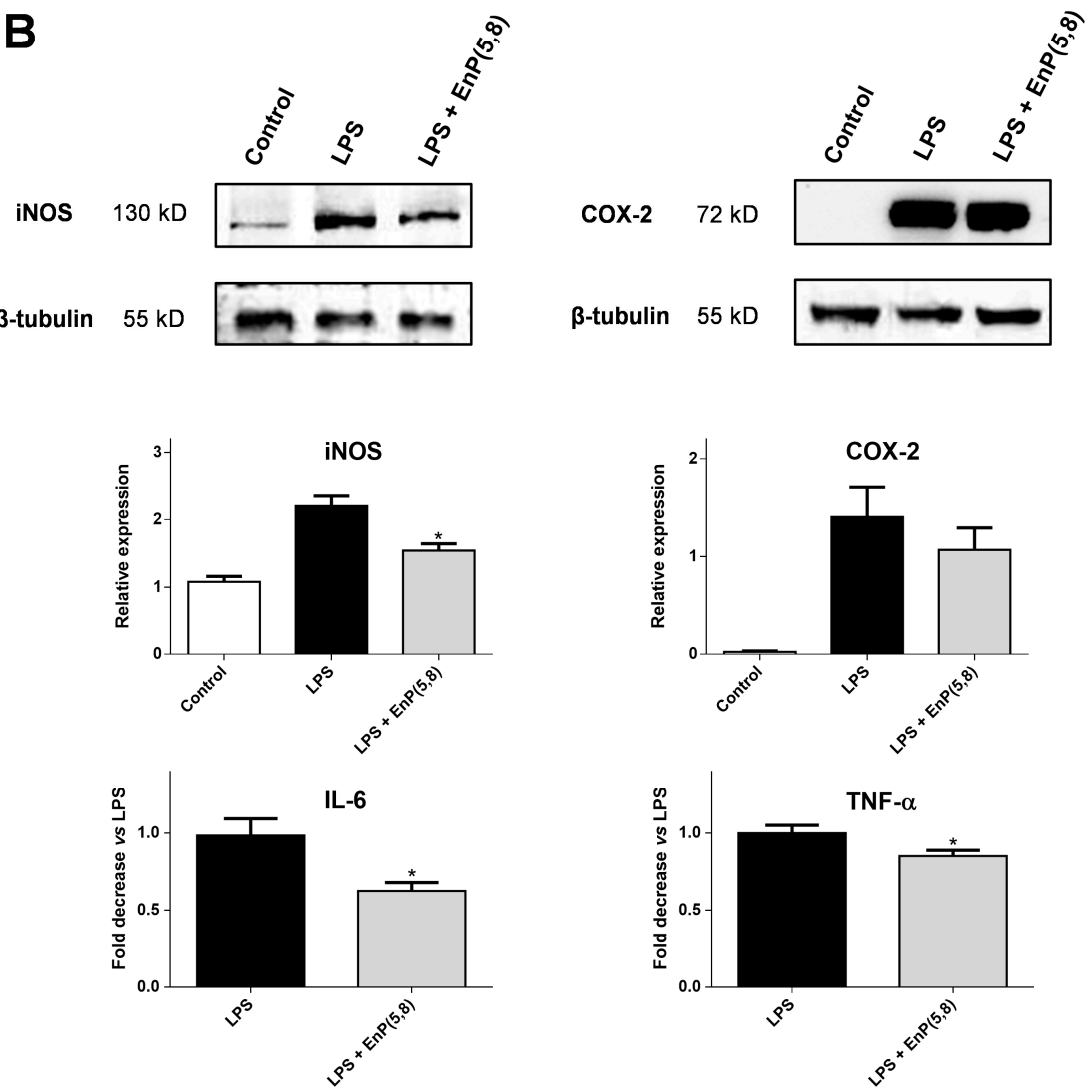

Figure 5. (A) Effect of EnP(5,8) on LPS-induced iNOS, cyclooxygenase-2 (COX-2), interleukin-6 (IL-6), and tumor necrosis factor alpha (TNF- $\alpha$ ) mRNA expressions. RAW 264.7 cells were treated for $4 \mathrm{~h}$ with LPS $(1 \mu \mathrm{g} / \mathrm{mL})$, with or without pre-incubation with $\operatorname{EnP}(5,8)$ for $2 \mathrm{~h}$. qPCR data were normalized to the reference gene, $\beta$-actin. (B) Effect of $\operatorname{EnP}(5,8)$ on LPS-induced iNOS, COX-2, IL-6, and TNF- $\alpha$ protein expression. RAW 264.7 cells were treated for $16 \mathrm{~h}$ with LPS $(1 \mu \mathrm{g} / \mathrm{mL})$, with or without pre-incubation with $\operatorname{EnP}(5,8)$ for $2 \mathrm{~h}$. LPS: lipopolysaccharide; $\operatorname{EnP}(5,8)$ : $5 \alpha, 8 \alpha$-epidioxycholest-6-en-3 $\beta$-ol at $10.4 \mu \mathrm{g} / \mathrm{mL}$ $(25 \mu \mathrm{M})$. Results are expressed as mean \pm SEM of at least three independent experiments. ${ }^{*} p<0.05$; ** $p<0.01$. 


\subsubsection{Arachidonic Acid Pathway Enzymes}

There are several functionally distinct enzymes involved in the arachidonic acid (AA) pathway: phospholipase $\mathrm{A}_{2}\left(\mathrm{PLA}_{2}\right)$, cyclooxygenase (COX), and lipoxygenase (LOX). Under inflammatory conditions, AA is released through the action of $\mathrm{PLA}_{2}$ upon the membrane phospholipids, being further metabolized via several different enzymatic machineries, namely the LOX and COX pathways, giving rise to a group of pro-inflammatory mediators called eicosanoids [23]. The eicosanoid production is considerably increased during inflammation, with leukotrienes and prostaglandins being products of LOX and COX activity, respectively $[25,26]$. In regard to COX, there are distinct isoforms such as COX-1, which is constitutively expressed in a variety of cell types being involved in their homeostasis, and the inducible isoform, COX-2, with a specific tissue distribution, thus constituting the most relevant target of anti-inflammatory drugs [26-28]. Therefore, we evaluated the ability of $\operatorname{EnP}(5,8)$ to inhibit the above-mentioned enzymes, at non-cytotoxic concentrations. Concerning PLA 2 and 5-LOX inhibition, $\operatorname{EnP}(5,8)$ demonstrated no measurable activity at concentrations up to $20.8 \mu \mathrm{g} / \mathrm{mL}$ ( $50 \mu \mathrm{M}$ ) (data not shown). Curiously, the structurally similar $5 \alpha, 8 \alpha$-epidioxy-(24S)-ergosta-6-en-3 $\beta$-ol, differing by the presence of an additional methyl group in C24, proved also to be ineffective against Apis mellifera bee venom $\mathrm{PLA}_{2}$ [29]. Recently, a structure-activity relationship (SAR) study comparing the 5-LOX inhibitory capacities of some ergosterol derivatives demonstrated the importance of the peroxy ring for greater activity [30]. However, despite $\operatorname{EnP}(5,8)$ presenting the peroxy group, it does not contain the C22-C23 olefinic double bound, which has been revealed to be essential for 5-LOX inhibition, thus corroborating our findings [30]. On the other hand, despite no significant differences have been found up to $10.4 \mu \mathrm{g} / \mathrm{mL}(25 \mu \mathrm{M}), \operatorname{EnP}(5,8)$ at $20.8 \mu \mathrm{g} / \mathrm{mL}(50 \mu \mathrm{M})$ significantly inhibited (23\%) COX-2 activity $(p<0.01)$, without notable inhibition of COX-1 (Figure 6). Even with its selectivity, the reported activity is weak when compared with celecoxib, a COX-2 inhibitor used in the clinic, which at the same concentration inhibits $74 \%$ of enzyme activity [31].

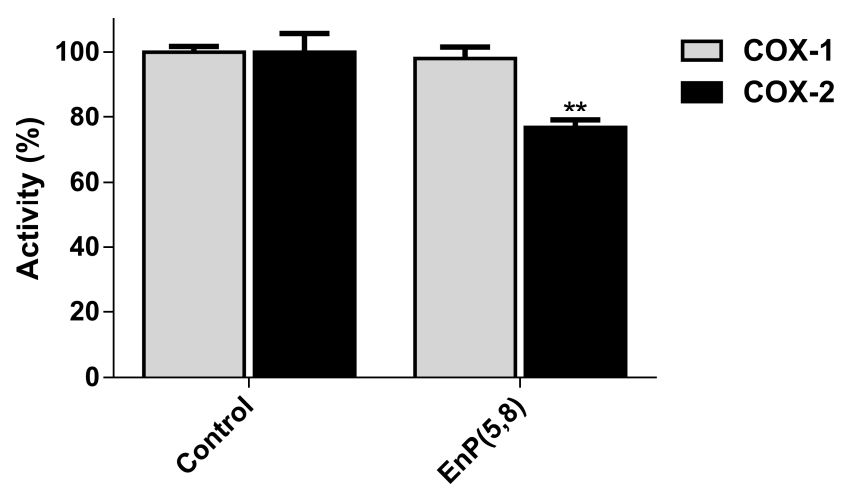

Figure 6. Effect of $\mathrm{EnP}(5,8)$ on $\mathrm{COX}-1$ and $\mathrm{COX}-2$ activity. $\mathrm{EnP}(5,8): 5 \alpha, 8 \alpha$-epidioxycholest-6-en-3 $\beta$-ol at $20.8 \mu \mathrm{g} / \mathrm{mL}(50 \mu \mathrm{M})$. Results are presented as mean \pm SEM of at least three experiments, performed in duplicate. ${ }^{* *} p<0.01$ compared to the respective control.

Noteworthy, a docking study carried out with sterols and triterpenoids proposed key structural requirements for COX binding, namely the presence of a tetracyclic skeleton, such as cholestane or stigmastane, the incorporation of an aliphatic chain in C17, and the presence of hydroxyl groups at $\mathrm{C} 3$ or $\mathrm{C} 6, \mathrm{EnP}(5,8)$ fulfilling these molecular features [32]. Despite the established structural requirements, few studies effectively evaluated the ability of this type of molecules to inhibit COX activity. Zhang, Mills and Nair (2003) screened the capacity of ergosterol and its peroxide, both containing the ergostane skeleton, on the inhibition of the two COX isoforms. They showed that the ergosterol peroxidation promotes a selectivity switch, leading to a higher COX-1 than COX-2 inhibitory activity [33]. In contrast, despite the presence of the peroxy ring in $\operatorname{EnP}(5,8)$, the selectivity to COX-2 was observed, suggesting that the substitution and unsaturation pattern of the $\mathrm{C} 17$ aliphatic chain, may also have a preponderant role in COX selectivity. As a matter of fact, Loza-Mejía and Salazar (2015) demonstrated that compounds 
with unsaturation in the aliphatic chain presented lower binding energies [32]. Overall, and due to the gastrointestinal tract side effects associated with the non-selective COX-2 inhibitors, $\operatorname{EnP}(5,8)$ may constitute an interesting molecule for the development of selective COX-2 inhibitors.

\section{Materials and Methods}

\subsection{Reagents and Standards}

LPS from Escherichia coli, sodium pyruvate, sulfanilamide, MTT, Triton X-100, N-(naphth-1-yl) ethylenediamine dihydrochloride, $\beta$-nicotinamide adenine dinucleotide reduced form (NADH), sodium deoxycholate, dimethyl sulfoxide (DMSO), trizma hydrochloride, trypan blue, soybean lipoxygenase (LOX) from Glycine max (L.) Merr. (Type V-S; EC 1.13.11.12), phospholipase $\mathrm{A}_{2}\left(\mathrm{PLA}_{2}\right)$ from honey bee (Apis mellifera) venom (EC.3.1.1.4), propan-2-ol, butan-1-ol, sodium nitroprusside (SNP), L-arginine monohydrochloride, diacetyl monoxime, antipyrine $\mathrm{E}, \mathrm{H}_{2} \mathrm{SO}_{4}$, bovine serum albumin (BSA), chloroform, and $N$-methyl-L-arginine acetate salt were from Sigma-Aldrich (St. Louis, MO, USA). 1,2-Dilinoleoyl-sn-glycero-3-phosphocholine (DL-PC) was from Larodan (Solna, Sweden). Dulbecco's Modified Eagle Medium (DMEM), fetal bovine serum (FBS), Hank's balanced salt solution (HBSS) and Pen Strep solution (penicillin 5000 units $/ \mathrm{mL}$ and streptomycin $5000 \mu \mathrm{g} / \mathrm{mL}$ ) were purchased from GIBCO, Invitrogen (Grand Island, NE, USA). $\beta$-Tubulin primary antibody, as well as anti-rabbit secondary antibody, were from Santa Cruz Biotechnology (Dallas, TX, USA). PureZOL ${ }^{\mathrm{TM}}$ reagent was from Bio-Rad (Hercules, CA, USA). KAPA SYBR ${ }^{\circledR}$ FAST qPCR Kit Master Mix (2X) Universal was from Kapa Biosystems (Boston, MA, USA). iNOS primary antibody was from Abcam (UK). COX-2 primary antibody, Qubit ${ }^{\mathrm{TM}}$ RNA HS assay kit, Qubit ${ }^{\mathrm{TM}}$ RNA IQ assay kit, SuperScript ${ }^{\mathrm{TM}}$ IV VILO ${ }^{\mathrm{TM}}$ Master Mix and primers were from Invitrogen by Thermo Fisher Scientific (Waltham, MA, USA). WesternBright ECL HRP substrate was from Advansta (Menlo Park, CA, USA). Potassium dihydrogen phosphate was purchased from Merck (Darmstadt, Germany). Methanol was from Chem-Lab (Zedelgem, Belgium) and hexane from Fisher Chemical (Loughborough, UK). Mouse IL-6 ELISA MAX ${ }^{\mathrm{TM}}$ Deluxe and Mouse TNF- $\alpha$ ELISA MAX ${ }^{\mathrm{TM}}$ Deluxe were purchased from BioLegend Inc. (San Diego, CA, USA). COX fluorescent inhibitor screening assay kit was from Cayman chemical (Ann Arbor, MI, USA).

\subsection{Sample}

A. depilans specimens were collected by hand at Praia da Memória (GPS coordinates $41^{\circ} 13^{\prime} 59.0^{\prime \prime} \mathrm{N}$, $\left.8^{\circ} 43^{\prime} 28.1^{\prime \prime} \mathrm{W}\right)$, north Portugal, at a depth of 1-3 feet, in June 2015. Specimens were immediately placed on ice and transported to the laboratory. The opisthobranch mollusks were then washed with sea water and kept at $-20{ }^{\circ} \mathrm{C}$, until use. Species identification was performed by Prof. Alexandre Lobo-da-Cunha (Centre of Marine and Environmental Research (CIIMAR), Porto, Portugal).

\subsection{Extraction}

A. depilans specimens ( $5.55 \mathrm{~kg}$, wet weight) were ground using an Ultra-Turrax homogenizer. The resulting biomass was exhaustively extracted with methanol, at room temperature. Afterwards, the extracting solution was filtered using a Büchner funnel and concentrated under reduced pressure. The remaining aqueous layer, derived from the water contained in the mollusks, was partitioned with hexane [34] and evaporated to dryness to give a non-polar fraction containing $10.07 \mathrm{~g}$ of organic residue.

\subsection{Extract Fractionation}

A part of the non-polar fraction of $A$. depilans extract $(2.0 \mathrm{~g})$ was submitted to a flash chromatography on a silica gel column $(90 \mathrm{~g}, 5.0 \mathrm{~cm} \times 20 \mathrm{~cm})$, using a gradient mixture of Hexane-EtOAc with increasing polarity, to afford eleven fractions (Fr1-Fr11). Fr6 (226.5 mg), eluted with 50\% of hexane in EtOAc, was further fractionated by flash chromatography on a silica gel column $(17 \mathrm{~g}, 2.0 \mathrm{~cm} \times 20 \mathrm{~cm})$, eluting with an isocratic mixture of hexane:EtOAc (40:60), to give nine sub-fractions (subFr1-subFr9). In order to exclude redundant compounds and/or chemical nullities, ${ }^{1} \mathrm{H}-\mathrm{NMR}$-based dereplication of the 
sub-fractions allowed the detection of cholesterol and mixtures of common glycerolipids, containing some unsaturated fatty acids, which are extremely explored and recognized for their anti-inflammatory properties. The steroidal endoperoxide was detected in subFr5 and subFr7, and since there are no studies addressing its anti-inflammatory effects, these sub-fractions were selected. SubFr5 (11.9 mg) was separated by HPLC (Agilent HP 1100) (see chromatogram in Figure S3A), using a Symmetry $300^{\mathrm{TM}}$ column, $3.5 \mu \mathrm{m}, 4.6 \mathrm{~mm} \times 150 \mathrm{~mm}$, IR detector (Agilent) with an isocratic mobile phase of $\mathrm{MeOH}: \mathrm{H}_{2} \mathrm{O}$ (98:2) and a flow of $1 \mathrm{~mL} / \mathrm{min}$ to afford $\operatorname{EnP}(5,8)\left(t_{\mathrm{R}}=4.75 \mathrm{~min}, 0.6 \mathrm{mg}\right)$. SubFr7 $(22.2 \mathrm{mg})$ was separated by HPLC (Agilent HP 1100) (see chromatogram in Figure S4), using a Prep Nova-Pak HR Sílica column, $60 \AA, 6 \mu \mathrm{m}, 3.9 \mathrm{~mm} \times 300 \mathrm{~mm}$, UV detector at $280 \mathrm{~nm}$ (Agilent), with an isocratic mobile phase of Hexane:EtOAc (80:20) and a flow of $1 \mathrm{~mL} / \mathrm{min}$ to afford $\operatorname{EnP}(5,8)\left(t_{\mathrm{R}}=15.08 \mathrm{~min}, 3.3 \mathrm{mg}\right)$. Total yield of $\operatorname{EnP}(5,8)$ is $3.54 \times 10^{-4 \%} \mathrm{w} / \mathrm{w}$.

${ }^{1} \mathrm{H}-\mathrm{NMR}\left(500 \mathrm{MHz}, \mathrm{CDCl}_{3}\right.$ ) 8: 6.51 (d, $\left.8.5 \mathrm{~Hz}, \mathrm{H7}\right) ; 6.24$ (d, $\left.8.5 \mathrm{~Hz}, \mathrm{H} 6\right) ; 3.96$ (m, H3); 2.11/1.90 (m, H4); 1.94/1.68 (m, H1); 1.83/1.52 (m, H2); 1.50/1.21 (m, H15); 1.49 (m, H25); 1.47 (m, H9); 1.21 (m, H12); $0.90(3 \mathrm{H}, \mathrm{d}, 6.5 \mathrm{~Hz}, \mathrm{H} 21) ; 0.88$ (3H, s, H19); 0.86 (3H, d, $6.5 \mathrm{~Hz}, \mathrm{H} 26), 0.86(3 \mathrm{H}, \mathrm{d}, 6.5 \mathrm{~Hz}, \mathrm{H} 27) ; 0.80$ (3H, $\mathrm{s}, \mathrm{H} 18)\left(\right.$ See ${ }^{1} \mathrm{H}-\mathrm{NMR}$ spectrum in Figure S5A).

${ }^{13} \mathrm{C}-\mathrm{NMR}\left(125 \mathrm{MHz}, \mathrm{CDCl}_{3}\right)$ ): $135.4(\mathrm{CH}, \mathrm{C} 6) ; 130.8(\mathrm{CH}, \mathrm{C} 7) ; 82.1$ (C, C5); $79.4(\mathrm{C}, \mathrm{C} 8) ; 66.5(\mathrm{CH}$, C3); 56.4 (CH, C17); $51.6(\mathrm{CH}, \mathrm{C} 14) ; 51.0(\mathrm{CH}, \mathrm{C} 9) ; 44.7$ (C, C13); $39.4\left(\mathrm{CH}_{2}, \mathrm{C} 12, \mathrm{C} 24\right) ; 36.9$ (C, C10); $36.9\left(\mathrm{CH}_{2}, \mathrm{C} 4\right) ; 35.9\left(\mathrm{CH}_{2}, \mathrm{C} 22\right) ; 35.2(\mathrm{CH}, \mathrm{C} 20) ; 34.7\left(\mathrm{CH}_{2}, \mathrm{C} 1\right) ; 30.1\left(\mathrm{CH}_{2}, \mathrm{C} 2\right) ; 28.2\left(\mathrm{CH}_{2}, \mathrm{C} 16\right)$; $28.0(\mathrm{CH}, \mathrm{C} 25) ; 23.8\left(\mathrm{CH}_{2}, \mathrm{C} 23\right) ; 23.4\left(\mathrm{CH}_{2}, \mathrm{C} 11\right) ; 22.8\left(\mathrm{CH}_{3}, \mathrm{C} 27\right) ; 22.5\left(\mathrm{CH}_{3}, \mathrm{C} 26\right) ; 20.6\left(\mathrm{CH}_{2}, \mathrm{C} 15\right)$; $18.6\left(\mathrm{CH}_{3}, \mathrm{C} 21\right) ; 18.2\left(\mathrm{CH}_{3}, \mathrm{C} 19\right) ; 12.6\left(\mathrm{CH}_{3}, \mathrm{C} 18\right)\left(\mathrm{See}^{13} \mathrm{C}\right.$-NMR spectrum in Figure $\left.55 \mathrm{~B}\right)$.

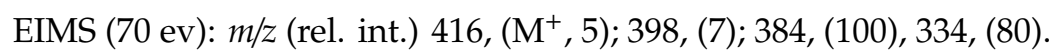

\subsection{Cell Culture}

RAW 264.7 macrophages were provided by American Type Culture Collection (LGC Standards S.L.U., Barcelona, Spain). Cells were cultured in DMEM supplemented with $10 \%$ FBS and $1 \%$ penicillin/streptomycin, and were incubated at $37^{\circ} \mathrm{C}$, in a humidified atmosphere of $5 \% \mathrm{CO}_{2}$.

\subsection{MTT Reduction Assay}

RAW 264.7 cells were seeded in 96-well plates at a density of 25,000 cells/well. After $24 \mathrm{~h}$ of growth, different concentrations of $A$. depilans extract/fractions/EnP $(5,8)$ were added and plates were incubated for $24 \mathrm{~h}$. Afterwards, mitochondrial activity was evaluated by the ability of metabolically active cells to convert yellow tetrazolium MTT to formazan. Results are expressed as percentage of the respective control and correspond to the mean \pm SEM of at least three independent experiments performed in triplicate.

\subsection{Membrane Integrity Assay}

$\mathrm{LDH}$ release into the media is usually used as a marker for loss of membrane integrity. To assess the release of this cytosolic enzyme, a protocol described by Silva et al. was followed [35]. Briefly, $24 \mathrm{~h}$ after the incubation of the cells with $A$. depilans extract/fractions/EnP(5,8), $20 \mu \mathrm{L}$ of culture media were removed to a 96-well plate. Then, $25 \mu \mathrm{L}$ of pyruvate was added to each well, followed by $230 \mu \mathrm{L}$ of NADH. LDH released was evaluated at $340 \mathrm{~nm}$, in a Multiskan GO plate reader (Thermo Fisher Scientific; Waltham, MA, USA), by monitoring the oxidation of NADH during the conversion of pyruvate to lactate. $1 \%$ Triton X-100 was used as positive control to assure cell lysis (30 min). All the results correspond to the fold-increase of absorbance in treated vs. untreated cells of, at least, three independent experiments performed in triplicate. 


\subsection{Determination of NO Levels}

RAW 264.7 cells were cultured in 96-well plates (35 000 cells/well) and incubated for $24 \mathrm{~h}$ at $37^{\circ} \mathrm{C}$ and $5 \% \mathrm{CO}_{2}$. Then, the medium of each well was replaced by different concentrations of A. depilans extract/fractions/EnP $(5,8)$ or media only, followed by a stimulation with $1 \mu \mathrm{g} / \mathrm{mL}$ of LPS $2 \mathrm{~h}$ later. After $22 \mathrm{~h}$ challenge with LPS, the quantity of NO in cell culture medium was measured according to a previously described method [16]. Briefly, the nitrite resulting from the conversion of NO in culture medium was quantified mixing $75 \mu \mathrm{L}$ of culture media with an equal volume of Griess reagent in a 96-well plate. The plate was incubated for $10 \mathrm{~min}$, in the dark, and the absorbance was measured at $560 \mathrm{~nm}$ in a Multiskan GO plate reader (Thermo Fisher Scientific; Waltham, MA, USA). Quercetin was used as positive control. The results correspond to the mean \pm SEM of at least three independent experiments performed in triplicate and are expressed as \% NO in cells exposed to LPS (positive control for NO production).

\section{9. ${ }^{-N O}$ Scavenging Assay}

-NO generated from SNP was measured according to a previously described method [15]. Briefly, the reaction mixture, containing $75 \mu \mathrm{L}$ of SNP in phosphate buffer, with or without $75 \mu \mathrm{L}$ of different concentrations of $\operatorname{EnP}(5,8)$ was incubated at room temperature for $1 \mathrm{~h}$, under light. The ${ }^{\bullet} \mathrm{NO}$ scavenging capacity was determined adding $75 \mu \mathrm{L}$ of Griess reagent and the absorbance was read at $560 \mathrm{~nm}$ after 10 min incubation in the dark. Three independent experiments were performed in triplicate.

\subsection{0. iNOS Inhibition Assay}

iNOS activity was evaluated based on the measurement of the two bio-products, NO and L-citrulline, after its action on L-arginine. RAW 264.7 cells (90000 cells/well) were seeded in 48-well plates and treated for $22 \mathrm{~h}$ with LPS $(1 \mu \mathrm{g} / \mathrm{mL})$. After this period of activation, which lead to an increased expression of iNOS enzyme, the culture medium was removed and cells were washed with HBSS and pre-incubated with different concentrations of $\operatorname{EnP}(5,8)$ in HBSS $(2.6-20.8 \mu \mathrm{g} / \mathrm{mL} ; 6.25-50 \mu \mathrm{M})$ for $1 \mathrm{~h}$. Simultaneously, $\mathrm{N}$-methyl-L-arginine (commercial iNOS inhibitor) was used as positive control. Then, L-arginine was added to each well, at a final concentration of $50 \mu \mathrm{M}$, and allowed to react during $2 \mathrm{~h}$. Afterwards, the levels of $\mathrm{NO}$ and L-citrulline were determined using the Griess reagent and a previously described method [15]. The results correspond to the mean \pm SEM of at least three independent experiments performed in duplicate.

\subsection{RNA Extraction, Quantification, Integrity, and Conversion}

RAW 264.7 cells (500000 cells/well) were seeded in 6-well plates and treated for $4 \mathrm{~h}$ with LPS $(1 \mu \mathrm{g} / \mathrm{mL})$, with or without pre-incubation with $\operatorname{EnP}(5,8)$ for $2 \mathrm{~h}$. Afterwards, the supernatant was removed and the cells were disrupted in $1 \mathrm{~mL}$ of PureZOL ${ }^{\mathrm{TM}}$ reagent. Then, the samples were transferred to a RNase-free tube and $0.2 \mathrm{~mL}$ of chloroform were added. The mixture was shaken vigorously for $15 \mathrm{~s}$. After $5 \mathrm{~min}$ incubation at room temperature, the samples were centrifuged at $12,000 \times \mathrm{g}$ for $15 \mathrm{~min}$ at $4{ }^{\circ} \mathrm{C}$. Following centrifugation, the aqueous phase containing the RNA was immediately transferred to a new RNase-free tube and $0.5 \mathrm{~mL}$ of isopropyl alcohol were added, and mixture was incubated at room temperature for $5 \mathrm{~min}$. Afterwards, the tubes were centrifuged at $12,000 \times \mathrm{g}$ for $10 \mathrm{~min}$ at $4{ }^{\circ} \mathrm{C}$, the RNA appearing as a white pellet on the side and bottom of the tube. Supernatant was carefully discarded and the RNA pellet was washed with $1 \mathrm{~mL}$ of $75 \%$ of ethanol. After vortexing, the mixture was centrifuged at $7500 \times g$ for $5 \mathrm{~min}$ at $4{ }^{\circ} \mathrm{C}$ and the supernatant was carefully discarded. Then, the RNA pellet was air-dried for about $5 \mathrm{~min}$ and reconstituted in $50 \mu \mathrm{L}$ of PCR grade water. Subsequently, the RNA was quantified in a Qubit 4 fluorometer (Invitrogen by Thermo Fisher Scientific; Waltham, MA, USA), using the Qubit ${ }^{\mathrm{TM}}$ RNA HS assay kit. The RNA quality and integrity was then evaluated using the Qubit ${ }^{\mathrm{TM}}$ RNA IQ assay kit. In order to obtain the complementary DNA, $1 \mu \mathrm{g}$ of RNA was mixed with $4 \mu \mathrm{L}$ SuperScript ${ }^{\mathrm{TM}}$ IV VILO ${ }^{\mathrm{TM}}$ Master Mix in a 
$20-\mu \mathrm{L}$ reaction. The reverse-transcribed reaction involved three steps: incubation at $25^{\circ} \mathrm{C}$ for $10 \mathrm{~min}$, incubation at $50{ }^{\circ} \mathrm{C}$ for $10 \mathrm{~min}$, and incubation at $85^{\circ} \mathrm{C}$ for $5 \mathrm{~min}$.

\subsection{2. qPCR Analysis}

qPCR analysis were conducted on multiple genes, namely iNOS, COX-2, IL-6, and TNF- $\alpha$ (Table 1). $\beta$-Actin was used as reference gene (Table 1 ). The primers were designed using the Primer-BLAST tool (NCBI, Bethesda, MD, USA) and synthesized by Thermo Fisher (Waltham, MA, USA), as listed in Table 1.

Table 1. qPCR target information.

\begin{tabular}{|c|c|c|c|c|}
\hline Gene & $\begin{array}{l}\text { Accession } \\
\text { Number }\end{array}$ & Primers & $\begin{array}{c}\text { Annealing } \\
\text { Temperature }\left({ }^{\circ} \mathrm{C}\right)\end{array}$ & $\begin{array}{l}\text { Amplicon } \\
\text { Length (bp) }\end{array}$ \\
\hline Nos2 (iNOS) & NM_001313921.1 & $\begin{array}{l}\text { F: CCGCCGCTCTAATACTTA } \\
\text { R: TTCATCAAGGAATTATACA }\end{array}$ & 58.0 & 121 \\
\hline Ptgs2 (COX-2) & NM_011198.4 & $\begin{array}{l}\text { F: } \\
\text { TGAGTACCGCAAACGCTTCT } \\
\text { R: } \\
\text { CAGCCATTTCСTTCTCTCСТGT }\end{array}$ & 60.0 & 74 \\
\hline Il6 (IL-6) & NM_001314054.1 & $\begin{array}{l}\text { F: } \\
\text { AGACAAAGCCAGAGTCCTTCAG } \\
\text { R: } \\
\text { TGACTCCAGCTTATCTCTTGGT }\end{array}$ & 59.0 & 75 \\
\hline $\operatorname{Tnf}(\mathrm{TNF}-\alpha)$ & NM_001278601.1 & $\begin{array}{l}\text { F: } \\
\text { ACTGAACTTCGGGGTGATCG } \\
\text { R: } \\
\text { GTGGTTTGTGAGTGTGAGGGT }\end{array}$ & 59.0 & 100 \\
\hline$A c t b$ ( $\beta$-actin) & NM_007393.5 & $\begin{array}{l}\text { F: } \\
\text { TATAAAACCCGGCGGCGCA } \\
\text { R: } \\
\text { TCATCCATGGCGAACTGGTG }\end{array}$ & 61.5 & 117 \\
\hline
\end{tabular}

Real-time qPCR was performed using KAPA SYBR ${ }^{\circledR}$ FAST qPCR Kit Master Mix (2X) Universal. The thermal cycling conditions were as follows: $3 \mathrm{~min}$ at $95^{\circ} \mathrm{C}$, followed by 40 cycles of denaturation at $95^{\circ} \mathrm{C}$ for $3 \mathrm{~s}$, specific annealing temperatures for each gene (Table 1 ) for $20 \mathrm{~s}$, and extension at $72{ }^{\circ} \mathrm{C}$ for $20 \mathrm{~s}$. The fluorescence signal was detected at the end of each cycle. The results were analyzed with qPCRsoft 4.0 supplied with the equipment qTOWER3 G (Analytik Jena AG, Germany), and a melting curve was used to confirm the specificity of the products. The expression levels of the target genes were normalized to the reference gene $\beta$-actin. At least five independent experiments were performed and all reactions were done in duplicate to confirm reproducibility. Results correspond to the mean \pm SEM and are expressed as fold decrease vs. LPS.

\subsection{Western Blot Analysis}

Western blot analysis was performed according to a previously described method [36]. Briefly, RAW 264.7 cells ( 500000 cells/well) were seeded in 6-well plates and treated for $16 \mathrm{~h}$ with LPS $(1 \mu \mathrm{g} / \mathrm{mL})$, with or without pre-incubation with $\operatorname{EnP}(5,8)$ for $2 \mathrm{~h}$. Afterwards, cells were washed with HBSS and lysed on ice, for 20 min with RIPA buffer, containing $1 \%$ of protease inhibitor cocktail. Then, cell debris were removed by microcentrifugation $(14,000 \times g$ for $15 \mathrm{~min})$, and supernatants were frozen at $-80{ }^{\circ} \mathrm{C}$. BSA was used as reference in order to quantify the total protein in cell lysates by the Bradford method [37]. Proteins $\left(40 \mu \mathrm{g}\right.$ ) were denatured at $70{ }^{\circ} \mathrm{C}$, separated on $10 \%$ sodium dodecylsulfate (SDS)-polyacrylamide minigels and transferred onto nitrocellulose membranes, using a Trans-Blot ${ }^{\circledR}$ Turbo (Bio-Rad; Hercules, CA, USA). Membranes were blocked for $1 \mathrm{~h}$ at room temperature with a solution of $5 \%$ skimmed milk powder in PBS $0.1 \%$ Triton X-100 and subsequently incubated overnight at $4{ }^{\circ} \mathrm{C}$ with specific antibodies against iNOS (1:200), COX-2 (1:2000) and $\beta$-tubulin (1:200). 
After washing, membranes were incubated with secondary antibody (1:1750) at room temperature for $1 \mathrm{~h}$. Immunoreactive bands were visualized by adding WesternBright ECL HRP substrate and detecting the luminescent signal in a ChemiDoc ${ }^{\mathrm{TM}}$ Imaging System (Bio-Rad, Hercules, CA, USA). The relative optical density of bands was quantified by densitometry and normalized with respect to $\beta$-tubulin (loading control). The results correspond to the mean \pm SEM of three independent experiments.

\subsection{Enzyme-Linked Immunosorbent Assay (ELISA)}

RAW 264.7 macrophages were seeded and treated for $16 \mathrm{~h}$ with LPS $(1 \mu \mathrm{g} / \mathrm{mL})$, with or without pre-incubation with $\operatorname{EnP}(5,8)$, as described in Section 3.13. The concentrations of the pro-inflammatory cytokines IL- 6 and TNF- $\alpha$ were determined in the supernatants using an ELISA kit, according to the manufacturer's instructions (BioLegend Inc.; San Diego, CA, USA). The concentration of each cytokine in the cell culture medium was normalized to total protein content, measured by Bradford method [28] using a BSA calibration curve as reference. Results correspond to the mean \pm SEM of at least four independent experiments and are expressed as fold decrease vs. LPS.

\subsection{PLA 2 Inhibition Assay}

The PLA 2 inhibition assay was based on an indirect enzymatic method, which uses 5-LOX as coupling enzyme [38]. Briefly, $20 \mu \mathrm{L}$ of PLA $2(1.75 \mu \mathrm{g} / \mathrm{mL})$ and $20 \mu \mathrm{L}$ of $5-\mathrm{LOX}(1.61 \mu \mathrm{g} / \mathrm{mL})$ in $3 \mathrm{mM}$ deoxycholate dissolved in $50 \mathrm{mM}$ Tris-HCL buffer ( $\mathrm{pH}$ 8.5) were mixed with $50 \mu \mathrm{L}$ of different concentrations of $\operatorname{EnP}(5,8)$ dissolved in the same buffer $(3.125-50 \mu \mathrm{M})$. The reaction was initiated with

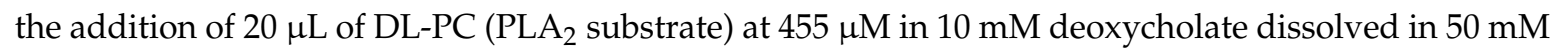
Tris-HCL buffer ( $\mathrm{pH}$ 8.5). Then, the linoleic acid released through $\mathrm{PLA}_{2}$ activity was oxidized by 5-LOX at $37^{\circ} \mathrm{C}$, the increase in absorbance at $234 \mathrm{~nm}$ being followed spectrophotometrically in a Multiskan GO plate reader (Thermo Fisher Scientific; Waltham, MA, USA). Three independent experiments were performed in triplicate.

\subsection{5-LOX Inhibition Assay}

The capacity of $\operatorname{EnP}(5,8)$ to inhibit 5-lipoxygenase was assessed according to a previously described method [39]. Briefly, $20 \mu \mathrm{L}$ of $\operatorname{EnP}(5,8), 20 \mu \mathrm{L}$ of soybean lipoxygenase (100 U) (Sigma-Aldrich; St. Louis, $\mathrm{MO}, \mathrm{USA}$ ) and $200 \mu \mathrm{L}$ of phosphate buffer ( $\mathrm{pH}$ 9) were pre-incubated at room temperature, for $5 \mathrm{~min}$, in a 96-well plate. Then, $20 \mu \mathrm{L}$ of linoleic acid $(4.18 \mathrm{mM}$ in ethanol) were added and the absorbance was monitored during $3 \mathrm{~min}$, at $234 \mathrm{~nm}$, using a Multiskan GO plate reader (Thermo Fisher Scientific; Waltham, MA, USA). Three independent experiments were performed in triplicate.

\subsection{COX-1 and COX-2 Inhibition Assay}

The assay was performed using the COX fluorescent inhibitor screening assay kit (Cayman chemical; Ann Arbor, MI, USA), with some modifications. It utilizes the peroxidase component of COXs and is based on the reaction between prostaglandin $\mathrm{G}_{2}\left(\mathrm{PGG}_{2}\right)$ (product of COX activity) and 10-acetyl-3,7-dihydroxyphenoxazine (ADHP), which produces a highly fluorescent compound, resorufin. Briefly, $60 \mu \mathrm{L}$ of assay buffer $(100 \mathrm{mM}$ Tris-HCl, $\mathrm{pH}$ 8.0), $5 \mu \mathrm{L}$ of hemin, $5 \mu \mathrm{L}$ of enzyme (either COX-1 or COX-2), and $5 \mu \mathrm{L}$ of $\operatorname{EnP}(5,8)$ were added in a black 96 -well plate. After 5 min of incubation at room temperature, $5 \mu \mathrm{L}$ of ADHP and $20 \mu \mathrm{L}$ of a solution containing arachidonic acid $(0.5 \mathrm{mM})$ and $\mathrm{KOH}(2.5 \mathrm{mM})$ were added to each well. After $2 \mathrm{~min}$ at room temperature, the fluorescence of resorufin was monitored with an excitation wavelength between $530-540 \mathrm{~nm}$ and an emission wavelength between 585-595 nm. SC-560 and DuP-697 inhibitors were used as positive controls to COX-1 and COX-2 assay, respectively. The results correspond to the mean \pm SEM of at least three independent experiments performed in duplicate. 


\subsection{Statistical Analysis}

Data analysis was performed using GraphPad Prism 6.01 Software (San Diego, CA, USA). Grubbs' test was used to detect and exclude outliers. Prior to the analysis, the data set was checked for normality of distribution using the Shapiro-Wilk test, ensuring that all data followed a normal distribution. Levels of significance were determined using unpaired Student's $t$-test where all columns of treatments were compared to the control. All data were expressed as mean \pm SEM. Values of $p<0.05$ were considered statistically significant.

\section{Conclusions}

In this work we evaluated the anti-inflammatory activity of a purified extract of $A$. depilans, and performed the bioguided isolation of the steroidal endoperoxide, $\operatorname{EnP}(5,8)$. In addition to the purified extract, the $\operatorname{EnP}(5,8)$ isolated from the most active sub-fraction demonstrated the ability to decrease the cellular NO levels in LPS-stimulated RAW 264.7 macrophages. Mechanistic studies evidenced that this decrease was due to a reduction in iNOS mRNA and protein expression. Moreover, $\operatorname{EnP}(5,8)$ also decreased the mRNA and protein expression of other inflammation mediators involved in the NF- $\mathrm{kB}$ pathway, namely COX-2, IL-6, and TNF- $\alpha$. Even with a non-significant decrease in COX-2 protein levels, the overall results suggest that $\operatorname{EnP}(5,8)$ may act by an inhibitory effect upon the NF- $\mathrm{KB}$ activation. Furthermore, enzymatic assays carried out with multiples enzymes involved in the AA pathway showed a selective inhibition of COX-2 by the same molecule. The above-mentioned findings provided further clues on the potential of $\operatorname{EnP}(5,8)$ as an anti-inflammatory agent.

Supplementary Materials: The following are available online at http://www.mdpi.com/1660-3397/17/6/330/s1, Figure S1. (A) Effect of the A. depilans non-polar extract fractions on MTT reduction and in NO levels of RAW 264.7 macrophages challenged with $1 \mu \mathrm{g} / \mathrm{mL}$ of LPS. Results are expressed as mean \pm SEM of at least three independent experiments. ${ }^{*} p<0.05,{ }^{* *} p<0.01,{ }^{* * *} p<0.001$. (B) Chemical structure of $\operatorname{EnP}(5,8)$ isolated from the non-polar fraction of $A$. depilans extract. Figure S2. Number of cycles (Ct values) required to amplify 2 ng of cDNA obtained from mRNA extracted from non-treated (control) and treated (LPS) RAW 264.7 macrophages. $\beta$-actin was used as reference gene. Results represent the mean \pm SEM of at least five independent experiments performed in duplicate. ${ }^{* * *} p<0.001$ (vs. control). Figure S3. (A) HPLC chromatogram of SubFr5. (B) ${ }^{1} \mathrm{H}-\mathrm{NMR}$ (500 MHz) spectra in $\mathrm{CDCl}_{3}$ of the peak eluted at $4.75 \mathrm{~min}$. Figure S4. HPLC chromatogram of SubFr7. Figure S5. (A) ${ }^{1} \mathrm{H}-\mathrm{NMR}(500 \mathrm{MHz})$, and (B) ${ }^{13} \mathrm{C}-\mathrm{NMR}(125 \mathrm{MHz})$ spectra in $\mathrm{CDCl}_{3}$ of the peak eluted at $15.08 \mathrm{~min}$ of Figure $\mathrm{S} 4$.

Author Contributions: R.B.P. conducted the experimental work and wrote the manuscript. C.J., J.R. and R.N. were responsible for the fractionation of $A$. depilans extract and isolation of $\operatorname{EnP}(5,8)$, as well as its structure elucidation. R.A.V. contributed to the development and optimization of iNOS inhibition assay. D.M.P. revised the manuscript and supervised the qPCR, Western-blot, ELISA, and respective data analyses. O.S., P.B.A. and P.V. were responsible for supervision, experimental design, and manuscript revision.

Acknowledgments: This work was supported by UID/QUI/50006/2019 with funding from FCT/MCTES through national funds. R. B. Pereira thanks FCT PhD Programme in Medicines and Pharmaceutical Innovation (i3DU) for the grant (PD/BD/113565/2015).

Conflicts of Interest: The authors declare no conflict of interest.

\section{References}

1. Pereira, R.B.; Andrade, P.B.; Valentão, P. Chemical diversity and biological properties of secondary metabolites from sea hares of Aplysia genus. Mar. Drugs 2016, 14, 39. [CrossRef] [PubMed]

2. Benkendorff, K. Molluscan biological and chemical diversity: Secondary metabolites and medicinal resources produced by marine molluscs. Biol. Rev. Camb. Philos. Soc. 2010, 85, 757-775. [CrossRef] [PubMed]

3. Pennings, S.C.; Paul, V.J. Sequestration of dietary secondary metabolites by three species of sea hares: Location, specificity and dynamics. Mar. Biol. 1993, 117, 535-546. [CrossRef]

4. Oliveira, A.P.; Lobo-da-Cunha, A.; Taveira, M.; Ferreira, M.; Valentão, P.; Andrade, P.B. Digestive gland from Aplysia depilans Gmelin: Leads for inflammation treatment. Molecules 2015, 20, 15766-15780. [CrossRef] [PubMed] 
5. Jiménez, C.; Quiñoá, E.; Castedo, L.; Riguera, R. Epidioxy sterols from the tunicates Dendrodoa grossularia and Ascidiella aspersa and the gastropoda Aplysia depilans and Aplysia punctata. J. Nat. Prod. 1986, 49, 905-909. [CrossRef]

6. Bu, M.; Yang, B.B.; Hu, L. Natural bioactive sterol $5 \alpha, 8 \alpha$-endoperoxides as drug lead compounds. Med. Chem. 2014, 4, 709-716. [CrossRef]

7. Wu, S.J.; Lu, T.M.; Lai, M.N.; Ng, L.T. Immunomodulatory activities of medicinal mushroom Grifola frondosa extract and its bioactive constituent. Am. J. Chin. Med. 2013, 41, 131-144. [CrossRef] [PubMed]

8. Miyamoto, T.; Honda, M.; Sugiyama, S.; Higuchi, R.; Komori, T. Studies on the constituents of marine opisthobranchia III. Isolation and structure of two 5,8 $\alpha$-epidioxysterols and a cholesteryl ester mixture from the albumen gland of Aplysia juliana. Liebigs Annalen der Chemie 1988, 1988, 589-592. [CrossRef]

9. Mou, X.-F.; Bian, W.-T.; Wang, C.-Y.; Shao, C.-L. Secondary metabolites isolated from the sea hare Aplysia pulmonica from the South China Sea. Chem. Nat. Compd. 2016, 52, 758-760. [CrossRef]

10. Gunatilaka, A.A.L.; Gopichand, Y.; Schmitz, F.J.; Djerassi, C. Minor and trace sterols in marine invertebrates. 26. Isolation and structure elucidation of nine new 5.alpha.,8.alpha.-epidoxy sterols from four marine organisms. J. Org. Chem. 1981, 46, 3860-3866. [CrossRef]

11. Aknin, M.; Viracaoundin, I.; Faure, R.; Gaydou, E.M. $5 \alpha, 8 \alpha$-Epidioxycholest-6-en-3- $\beta$-ol from three cone snails of the Indian ocean. J. Am. Oil Chem. Soc. 1998, 75, 1679-1681. [CrossRef]

12. Ioannou, E.; Abdel-Razik, A.F.; Zervou, M.; Christofidis, D.; Alexi, X.; Vagias, C.; Alexis, M.N.; Roussis, V. $5 \alpha, 8 \alpha$-Epidioxysterols from the gorgonian Eunicella cavolini and the ascidian Trididemnum inarmatum: Isolation and evaluation of their antiproliferative activity. Steroids 2009, 74, 73-80. [CrossRef] [PubMed]

13. Minh, C.V.; Kiem, P.V.; Huong le, M.; Kim, Y.H. Cytotoxic constituents of Diadema setosum. Arch. Pharm. Res. 2004, 27, 734-737. [CrossRef] [PubMed]

14. Clark, K.E.; Capper, A.; Della Togna, G.; Paul, V.J.; Romero, L.I.; Johns, T.; Cubilla-Rios, L.; Capson, T.L. Ecology- and bioassay-guided drug discovery for treatments of tropical parasitic disease: 5alpha, 8alpha-epidioxycholest-6-en-3beta-ol isolated from the mollusk Dolabrifera dolabrifera shows significant activity against Leishmania donovani. Nat. Prod. Commun. 2013, 8, 1537-1540. [CrossRef] [PubMed]

15. Pereira, R.B.; Taveira, M.; Valentao, P.; Sousa, C.; Andrade, P.B. Fatty acids from edible sea hares: anti-inflammatory capacity in LPS-stimulated RAW 264.7 cells involves iNOS modulation. RSC Adv. 2015, 5, 8981-8987. [CrossRef]

16. Pereira, R.B.; Pinto, D.C.G.A.; Pereira, D.M.; Gomes, N.G.M.; Silva, A.M.S.; Andrade, P.B.; Valentão, P. UHPLC-MS/MS profiling of Aplysia depilans and assessment of its potential therapeutic use: Interference on iNOS expression in LPS-stimulated RAW 264.7 macrophages and caspase-mediated pro-apoptotic effect on SH-SY5Y cells. J. Funct. Foods 2017, 37, 164-175. [CrossRef]

17. Pereira, R.B.; Almeida, A.A.; Pereira, D.M.; Silva, O.; Andrade, P.B.; Pinto, E.; Valentão, P. Trace elements in wild edible Aplysia species: Relationship with the desaturation-elongation indexes of fatty acids. Chemosphere 2018, 208, 682-690. [CrossRef] [PubMed]

18. Sharma, J.N.; Al-Omran, A.; Parvathy, S.S. Role of nitric oxide in inflammatory diseases. Inflammopharmacology 2007, 15, 252-259. [CrossRef]

19. Huang, C.-Y.; Chang, C.-W.; Tseng, Y.-J.; Lee, J.; Sung, P.-J.; Su, J.-H.; Hwang, T.-L.; Dai, C.-F.; Wang, H.-C.; Sheu, J.-H. Bioactive steroids from the formosan soft coral Umbellulifera petasites. Mar. Drugs 2016, 14, 180. [CrossRef]

20. Castaneda, O.A.; Lee, S.C.; Ho, C.T.; Huang, T.C. Macrophages in oxidative stress and models to evaluate the antioxidant function of dietary natural compounds. J. Food Drug Anal. 2017, 25, 111-118. [CrossRef]

21. Lawrence, T. The nuclear factor NF-kappaB pathway in inflammation. Cold Spring Harb. Perspect. Biol. 2009, 1, a001651. [CrossRef] [PubMed]

22. Hong, Y.J.; Reum Jang, A.; Jang, H.J.; Yang, K.S. Inhibition of nitric oxide production, iNOS and COX-2 expression of ergosterol derivatives from Phellinus pini. Natural Product Sciences 2012, 18, 147-152.

23. Lu, Y.; Lin, Y.-C.; Wen, Z.-H.; Su, J.-H.; Sung, P.-J.; Hsu, C.-H.; Kuo, Y.-H.; Chiang, M.Y.; Dai, C.-F.; Sheu, J.-H. Steroid and cembranoids from the Dongsha atoll soft coral Lobophytum sarcophytoides. Tetrahedron 2010, 66, 7129-7135. [CrossRef]

24. Zhou, X.; Sun, J.; Ma, W.; Fang, W.; Chen, Z.; Yang, B.; Liu, Y. Bioactivities of six sterols isolated from marine invertebrates. Pharm. Biol. 2014, 52, 187-190. [CrossRef] [PubMed] 
25. Barnig, C.; Frossard, N.; Levy, B.D. Towards targeting resolution pathways of airway inflammation in asthma. Pharmacol. Ther. 2018, 186, 98-113. [CrossRef]

26. Prasher, P.; Mudila, H.; Sharma, M.; Khati, B. Developmental perspectives of the drugs targeting enzyme-instigated inflammation: A mini review. Med. Chem. Res. 2019, 28, 417-449. [CrossRef]

27. Pairet, M.; Engelhardt, G. Distinct isoforms (COX-1 and COX-2) of cyclooxygenase: Possible physiological and therapeutic implications. Fundam. Clin. Pharmacol. 1996, 10, 1-15. [CrossRef]

28. Kam, P.C.A.; See, A.U.L. Cyclo-oxygenase isoenzymes: Physiological and pharmacological role. Anaesthesia 2000, 55, 442-449. [CrossRef]

29. Gao, J.-M.; Wang, M.; Liu, L.-P.; Wei, G.-H.; Zhang, A.-L.; Draghici, C.; Konishi, Y. Ergosterol peroxides as phospholipase A2 inhibitors from the fungus Lactarius hatsudake. Phytomedicine 2007, 14, 821-824. [CrossRef]

30. Khayat, M.T.; Ibrahim, S.R.M.; Mohamed, G.A.; Abdallah, H.M. Anti-inflammatory metabolites from endophytic fungus Fusarium sp. Phytochem. Lett. 2019, 29, 104-109. [CrossRef]

31. Chang, M.C.; Uang, B.J.; Tsai, C.Y.; Wu, H.L.; Lin, B.R.; Lee, C.S.; Chen, Y.J.; Chang, C.H.; Tsai, Y.L.; Kao, C.J.; et al. Hydroxychavicol, a novel betel leaf component, inhibits platelet aggregation by suppression of cyclooxygenase, thromboxane production and calcium mobilization. Br. J. Pharmacol. 2007, 152, $73-82$. [CrossRef] [PubMed]

32. Loza-Mejía, M.; Salazar, J. Sterols and triterpenoids as potential anti-inflammatories: Molecular docking studies for binding to some enzymes involved in inflammatory pathways. J. Mol. Graph. Model. 2015, 62, 18-25. [CrossRef] [PubMed]

33. Zhang, Y.; Mills, G.L.; Nair, M.G. Cyclooxygenase inhibitory and antioxidant compounds from the fruiting body of an edible mushroom, Agrocybe aegerita. Phytomedicine 2003, 10, 386-390. [CrossRef] [PubMed]

34. Ebada, S.S.; Edrada, R.A.; Lin, W.; Proksch, P. Methods for isolation, purification and structural elucidation of bioactive secondary metabolites from marine invertebrates. Nat. Protoc. 2008, 3, 1820-1831. [CrossRef] [PubMed]

35. Silva, C.T.; Andrade, P.B.; Paiva-Martins, F.; Valentão, P.; Pereira, D.M. In Vitro anti-inflammatory and cytotoxic effects of aqueous extracts from the edible sea anemones Anemonia sulcata and Actinia equina. Int. J. Mol. Sci. 2017, 18, 653. [CrossRef] [PubMed]

36. Pereira, D.M.; Correia-da-Silva, G.; Valentão, P.; Teixeira, N.; Andrade, P.B. Anti-inflammatory effect of unsaturated fatty acids and ergosta-7,22-dien-3-ol from Marthasterias glacialis: Prevention of CHOP-mediated ER-stress and NF- $\mathrm{kB}$ activation. PLoS ONE 2014, 9, e88341. [CrossRef] [PubMed]

37. Bradford, M.M. A rapid and sensitive method for the quantitation of microgram quantities of protein utilizing the principle of protein-dye binding. Anal. Biochem. 1976, 72, 248-254. [CrossRef]

38. Jiménez, M.; Cabanes, J.; Gandía-Herrero, F.; Escribano, J.; García-Carmona, F.; Pérez-Gilabert, M. A continuous spectrophotometric assay for phospholipase A2 activity. Anal. Biochem. 2003, 319, 131-137. [CrossRef]

39. Kachmar, M.R.; Oliveira, A.P.; Valentão, P.; Gil-Izquierdo, A.; Domínguez-Perles, R.; Ouahbi, A.; Badaoui, K.E.; Andrade, P.B.; Ferreres, F. HPLC-DAD-ESI/MSn phenolic profile and in vitro biological potential of Centaurium erythraea Rafn aqueous extract. Food Chem. 2019, 278, 424-433. [CrossRef] [PubMed]

(C) 2019 by the authors. Licensee MDPI, Basel, Switzerland. This article is an open access article distributed under the terms and conditions of the Creative Commons Attribution (CC BY) license (http://creativecommons.org/licenses/by/4.0/). 